\title{
Publisher Correction: lessons learned at the biology-geology interface
}

\section{Jayme Feyhl-Buska}

Nature Reviews Earth \& Environment (2020) https://doi.org/10.1038/s43017-020-0034-1

Published online 27 February 2020

The publication date of this article was the $27^{\text {th }}$ February 2020 , not the $10^{\text {th }}$ February 2020 as originally stated.

https://doi.org/10.1038/s43017-020-0041-2 I Published online 9 March 2020

(c) Springer Nature Limited 2020 